\section{Samhandlingsreformen under lupen}

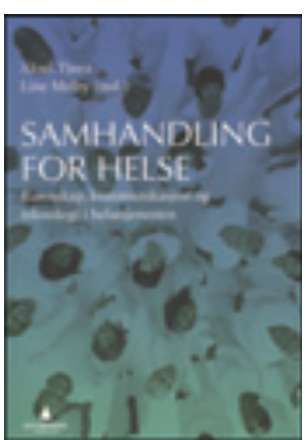

Aksel Tjora, Line Melby, red.

Samhandling for helse

Kunnskap, kommunikasjon og teknologi

i helsetjenesten. 339 s, tab, ill. Oslo: Gyldendal

Akademisk, 2013. Pris NOK 425

ISBN 978-82-05-42552-1

I Samhandling for helse analyseres samhandlingsreformens muligheter for å lykkes ut fra et samfunnsfaglig perspektiv. Det beskrives hvordan reformen skal bidra til at helsepersonell motiveres av felles helsefaglige og samfunnsmessige interesser i stedet for faglige særinteresser. Legenes rolle i tverrfaglig samarbeid og deres vilkår for å kunne bidra i slike sammenhenger problematiseres.

Hvordan legenes rolle i ledelse av sykehus er endret, vektlegges $i$ et eget kapittel. På tross av tidligere trender med generalistledere ser det ut til at skjerpede kvalitetskrav fra pasienter og tilsynsmyndigheter gjør at man i økende grad rekrutterer medisinskfaglig ekspertise i ledelsen. Andelen ledere med medisinsk bakgrunn på avdelings- og divisjonsnivå har vist seg å ligge stabilt på omkring $40 \%$ fra perioden $2003-09$.

Betydningen av å bygge relasjoner basert på tillit og respekt mellom ulike fagmiljøer og å sette av tid og dedikerte arenaer for dette demonstreres $i$ en prosess for å samlokalisere akuttkirurgien ved et sykehus. Teknologi som kan forenkle og gjøre pasientenes tilværelse tryggere, blir illustrert ved GPS-bruk for å lokalisere demente som har gått seg bort.

Det diskuteres i hvilken grad sentrale forslag i samhandlingsreformen, som etablering av interdisiplinære fora og møteplasser og endrede finansielle rammevilkår, skal kunne prioriteres i et helsevesen preget av New Public Management som styringsteori. Reformens mål om at ulike bidragsytere skal prioritere felles mål foran egne særinteresser, gis små sjanser for å lykkes.

Denne boken retter seg mot helsepersonell, forskere, byråkrater, og andre som interesserer seg for helsetjenestenestenes organisering. Kapitlene har forskjellige forfattere, som beskriver ulike detaljer knyttet til organisering, koordinering og samarbeid i og mellom enheter i helsetjenesten.

Detaljer i samhandlingsprosessene vektlegges mer enn analyse av hvordan samhandlingen påvirkes av helsetjenestenes organisering og finansiering. Jeg savner en analyse av i hvilken grad samhandling mellom spesialisthelsetjenesten, primærhelsetjenesten og fastlegeordningen er påvirket av de skarpe skillelinjene mellom deres finansieringsordninger.

\section{Ellen Tveter Deilkås}

Overlege, Forskningssenteret og Nevroklinikken

Akershus universitetssykehus

\section{Obligatorisk!}

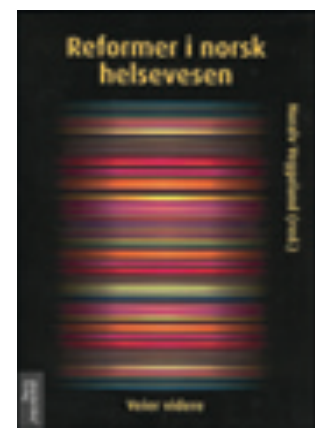

Noralv Veggeland, red.

Reformer i norsk helsevesen

Veier videre. 272 s, tab, ill. Trondheim:

Akademika forlag, 2013. Pris NOK 345

ISBN 978-82-321-0291-4
Her leverer professor Noralv Veggeland (red.) og et knippe av landets fremste samfunnsforskere og helsetjenesteforskere en verdifull intellektuell tjeneste i den spente helsepolitiske situasjonen vi befinner oss i. De henvender seg til ansvarlige politikere, ledere og byråkrater og til fagforeninger, fagfolk, studenter og forskere. Dette bør være obligatorisk lesning også for seriøse journalister og helsetjenesteaktivister.

De forskjellige kapitlene opplyser sentrale temaer i helsereformene og viser hele veien linjene til historien her hjemme - hvor de «nye ideene» er importert fra, i hvilken ideologisk kontekst de er oppstått og hvilke erfaringer man har gjort med tilsvarende ideer og reformer andre steder i verden. Alt dette er det nødvendig for oss å vite mer om.

Forskere på dette nivået stiller høye krav til sin faglige integritet, desto sterkere virker det når deres konklusjoner griper inn i de politiske debattene. Det mest oppsiktsvekkende i denne utgivelsen er kanskje at professor Bjarne Jensen viser hvordan planleggingen av både foretaksreformen og samhandlingsreformen var uansvarlig lemfeldig og at den økonomiske argumentasjonen reformene ble solgt inn med politisk, viser seg å være falsk.

Det er også foruroligende når professor Veggeland viser hvilke uoverkommelige problemer som ligger latent $i$ samhandlingsreformen, og hvordan disse problemene, når de har kommet til overflaten, har tvunget myndighetene $\mathrm{i}$ andre land til å reversere tilsvarende reformer. Når dr. Tor Helge Pedersen viser hvordan sykehusovergripende divisjoner heller ikke ser ut til å fungere andre steder i verden, er det også verdt å merke seg.

I et ambisiøst avslutningskapittel, Morgendagens klinikk, stiller professor Ole Berg de «reduksjonistiske» vitenskapstradisjonene hvor kontekstuavhengighet er et ideal - opp mot den «systemorienterte» tilnærmingen til kunnskap og forståelse. Med forfatterens forbehold i mente er dette stimulerende og utfordrende lesning. Selv om den reduksjonistiske tilnærmingen har gitt fantastiske resultater innen medisin og teknologi, er selve legevitenskapen systemorientert, kontekstorientert og prosessorientert av natur. Dette gjelder også politikk, økonomi, ledelse og samarbeid.

En prosessorientert systemforståelse er mer avansert fordi den kan involvere reduksjonistisk tilnærming, mens reduksjonistisk mål- og resultatstyring ignorerer prosessforståelse og kontekstforståelse og avskjærer seg dermed fra systemforståelse - og følgelig fra positiv kontroll. Slike moderne forestillinger blir viktige når helsearbeidere må forsvare sin faglige integritet mot industrialiseringen av helsesektoren.

Johan Nygaard

Skribent

Asker 